\title{
Učestalost upotrebe likovno-umjetničkog djela u nastavi likovne kulture
}

Marija Brajčić*

mbrajcic@ffst.hr

Mara Šućur***

sucurmara@gmail.com https://doi.org/10.31192/np.17.1.4

UDK: 37.091.31:73/75

Izvorni znanstveni rad / Original scientific paper

Primljeno: 2. listopada 2018.

Prihvaćeno: 11. siječnja 2019.

Upoznavanje učenika s likovno-umjetničkom djelom značajan je cilj predmeta likovne kulture. Utjecaj likovno-umjetničkog djela na dječju percepciju, moć uočavanja kao i razvoj estetskih vrijednosti iznimno je važan za daljnji razvoj $i$ napredak učenika ne samo u likovnoj kulturi, već i u ostalim odgojno-obrazovnim područjima. Znanstvena teorija drži da ni jedan nastavni sat likovne kulture ne bi trebao proteći bez prikaza likovno- umjetničkog djela. Cilj istraživanja je bio utvrditi učestalost upotrebe likovno-umjetničkog djela u nastavi likovne kulture u nižim razredima osnovne škole. Uspoređeni su odgovori 80 učitelja s područja Splitsko-dalmatinske županije i 80 studenata četvrte i pete godine Učiteljskog studija u Splitu koji u okviru studija održavaju ispitne satove iz likovne kulture. Svrha je istraživanja bila utvrditi koliko učitelji ili studenti koriste likovna djela na nastavi likovne kulture i na koji način ih predstavljaju učenicima. Istraživanje je pokazalo da većina navedenih varijabli ide u korist studentima, izuzev pitanja koja se odnose na pokazivanja figurativnih djela na nastavi likovne kulture i pokazivanje djela domaćih umjetnika na nastavi likovne kulture, kod kojih ne postoji statistička značajnost. I učitelji u studenti se u podjednakoj mjeri odlučuju za figurativna djela i djela domaćih umjetnika. Ključne riječi: likovna kultura, likovno djelo, učitelji, studenti.

\footnotetext{
* Doc. dr. sc. Marija Brajčić, Filozofski fakultet Sveučilišta u Splitu, Poljička cesta 35, HR-21000 Split.

*:* Mara Šućur, mag. prim. obr.; Put Šućura 9, HR-21262 Kamenmost, Imotski.
} 


\section{Uvod}

Ni jedno društvo ne može opstati bez svoje kulture: jezika, običaja, moralnih i religijskih vrijednosti te umjetnosti. ${ }^{1}$ Likovna kultura i umjetnost nezaobilazna su i nezamjenjiva komponenta opće kulture pojedinca i društva, općedruštvene kulture i stvaralačke svijesti. ${ }^{2}$ Likovna umjetnost predstavlja univerzalnu društvenu vrijednost o kojoj možemo govoriti kao o autonomnom području iskazivanja duhovnih kategorija ljudskog opstanka. ${ }^{3}$ Stoga je susret s umjetničkim djelom značajan čimbenik odgoja i obrazovanja djece i mladih. Utjecaj likovno-umjetničkog djela na dječju percepciju, moć uočavanja kao i razvoj estetskih vrijednosti kod djeteta je neizmjerno važan za daljnji razvoj i napredak učenika ne samo u likovnoj kulturi, već i u ostalim odgojnoobrazovnim područjima. Prema tome, prikazivanje likovno-umjetničkog djela na nastavi likovne kulture od izuzetne je važnosti, čak i nužno za shvaćanje likovnosti.

Značenje podučavanja likovne umjetnosti u osnovnoj školi je višestruko jer ono nije samo kompleksno učenje, već i konkretno iskustvo doživljaja, shvaćanja i prihvaćanja svijeta utemeljenog na cjelokupnoj povijesti čovječanstva. ${ }^{4}$ Prema tumačenju Warburga, ${ }^{5}$ likovno-umjetnička djela ne mogu se samo ograničiti na proučavanje isključivo vizualnog aspekta slike, već je često, da bi se uopće razumjelo umjetničko djelo, potrebno poznavati proučavanja antropologa, psihoanalitičara i povjesničara. Također i povijest filozofije, religije, ideologije i cjelokupne povijesne, političke i društvene situacije. U likovno-umjetničkom djelu sadržana je uzročno-posljedična povezanost s vremenom, prostorom i kulturom u kojoj je stvoreno, ono nadilazi prostor i vrijeme u kojem je nastalo i pridonosi razvoju čovjekova estetskog i kulturnog senzibiliteta. Likovnoumjetnička djela, kao dio svijeta raznolikih vizualnih sadržaja, neprestan su dijalog između stvaratelja i primatelja. ${ }^{6}$ Treba ih shvatiti kao autonomne osobe koje čekaju osobu za razgovor u svome interpretu, čime kvaliteta umjetničkog djela i njegova hermeneutičkoga sugovornika određuju stupanj uspješnosti

${ }^{1}$ Usp. Marija BRAJČIĆ, Arheološki parkovi u Hrvatskoj, Split, Filozofski fakultet Sveučilišta u Splitu, 2014, 29.

${ }^{2}$ Usp. Marija BRAJČIĆ, Značaj kulturne baštine i etnografskih izvora u nastavi likovne kulture, u: R. Bacalja (ur.), Djetinjstvo, razvoj i odgoj, Zadar, Sveučilište u Zadru, Stručni odjel za izobrazbu učitelja i odgojitelja predškolske djece, 2002, 67-70.

${ }^{3}$ Usp. Marija BRAJČIĆ, Dubravka KUŠČEVIĆ, Dijete i likovna umjetnost. Doživljaj likovnog djela, Split, Filozofski fakultet Sveučilišta u Splitu, 2016, 7.

${ }^{4}$ Usp. Dubravka KUŠČEVIĆ, Likovno-umjetnička djela u nastavi likovne kulture, Zbornik radova Filozofskog fakulteta u Splitu, 6-7 (2013-2014) 6-7, 43-54.

${ }^{5}$ Usp Aby WARBURG, Gesammelete Schriften, I-II, Leipzig-Berlin 1932, prema Jan BIATOSTOCKI, Povijest umjetnosti i humanističke znanosti, Zagreb, Grafički zavod Hrvatske, 1986, 28.

${ }^{6}$ Usp. Kuščević, nav. dj., 46. 
shvaćanja, tumačenja i doživljaja promatranog likovno-umjetničkog djela. ${ }^{7}$ »Pravo umjetničko djelo nije samo izraz, već i saopćenje i u tom smislu nije samo govor, već i razgovor. $\ll^{8}$

Umjetnička djela nisu statična i zatvorena činjenica, već otvorena dinamički promjenjiva stvarnost s vlastitim kontinuitetom i identitetom. ${ }^{9}$ Otvorenost likovnog djela traži svoga interpretatora, umjetničko djelo predmet je komunikacije i kao takvo teži dvosmjernoj komunikaciji, što znači da bismo učenike trebali osposobiti za komunikaciju s likovno-umjetničkim djelima koja nisu apriori stvorena za njih. Likovno-umjetničko djelo zahtijeva percepciju i recepciju, u protivnom ne ostvaruje svoju svrhu. Da bi djeca shvatila značenja likovno-umjetničkih djela, potrebno ih je uvoditi u slojevitost likovno-umjetničkog djela kako bi razvijali svoju vizualno-likovnu, a time i kulturno-estetsku osjetljivost. Razumijevanje likovno-umjetničkog djela zahtjevan je zadatak za učenike. Shvatiti raznolikost umjetničkih stilova, usvojiti likovni jezik, shvatiti često suprotstavljena umjetnička razdoblja, nije lako i potrebno je postupno poticati razvoj umjetničkog razumijevanja, što je ujedno i jedan od ciljeva vizualno-likovnog odgoja i obrazovanja. Susret s likovno-umjetničkim djelom trebalo bi primjereno ostvarivati na svim stupnjevima školovanja učenika, kako bi se sposobnost estetskog vrednovanja učenika razvijala usporedno s njihovim kognitivnim i emocionalnim sposobnostima. ${ }^{10}$

\section{Pristup likovnom djelu}

Prihvaćanje likovno-umetničkih djela kod učenika razvija se u komunikaciji sa samim djelom, a temelji se na kulturi opažanja, promatranja, doživljavanja, promišljanja i interpretiranja doživljenih sadržaja. »Umjetnička su djela poruke koje prenose činjenice, misli, osjećaje; njihovo proučavanje pripada novonastalom svežderu pod nazivom 'teorija komunikacije'.«"11

Feldman ${ }^{12}$ i Chapman, ${ }^{13}$ govoreći o estetskom odgoju mlađe djece, drže da već kod predškolskog djeteta postoji kapacitet za estetski odgovor. Feldman tvrdi da dijete već u vrtiću može spontano izvesti iste radnje kao što ih izvode i profesionalni likovni kritičari - opisivanje, analiziranje, interpretiranje i

\footnotetext{
${ }^{7}$ Usp. Jure ZOVKO, Filozofija i kultura - primjeri estetičkog kultiviranja u doba recesije duha, Zagreb, Naklada Jurčić, 2009, 48-59.

8 Arnold HAUSER, Sociologija umjetnosti, Zagreb, Školska knjiga, 1986, 4.

${ }^{9}$ Usp. Stanko BAKOVIĆ, Sociologija umjetnosti, Zagreb, Spektar, 1985, 124.

${ }^{10}$ Usp. Kuščević, nav. dj., 46.

${ }^{11}$ Nelson GOODMAN, Jezici umjetnosti. Pristup teoriji simbola, Zagreb, Kruzak, 2002, 214.

${ }^{12}$ Edmund B. FELDMAN, Becoming Human through Art, Englewood Cliffs N. J., Prentice Hall, 1970.

${ }^{13}$ Laura CHAPMAN, Approaches to Art in Education, New York, Harcourt Brace Jovanovich, $1978,128$.
} 
prosuđivanje, ali po nasumičnom redoslijedu. ${ }^{14}$ Podučavanje je u umjetnosti velikim dijelom posao usustavljivanja djetetove neukrotive želje za razgovorom o umjetnosti. ${ }^{15}$ Galerije i muzeji nisu samo mjesta u kojima se čuvaju i skladište umjetnička djela, već su institucije gdje se mogu na najbolji način ostvariti kontakti učenja i poučavanja na originalnim umjetninama. ${ }^{16}$ Neki autori naglašavaju važnost direktnog kontakta djeteta i umjetnine jer se time uspješno realizira kontekstualno učenje koje omogućava upoznavanje objekta znanja, ali i uvažavaju kulturna, kontekstualna i osobna obilježja. ${ }^{17}$ Ako poučavanje nije moguće ostvariti u muzeju, na izložbi ili u galeriji, autori drže da je svakako potrebno promatrati umjetnička djela na reprodukcijama u učionici. Bez obzira na to gledaju li učenici reprodukciju ili originalnu umjetninu, važno je da aktivno sudjeluju u komunikaciji s ponuđenim likovnim djelom. Komuniciranje s umjetnošću trebalo bi proizlaziti iz kombinacije iskustvenog i teorijskog učenja. ${ }^{18}$ Iskustveno učenje zahtijeva od promatrača da fizički susretne likovnoumjetničko djelo, dok teorijsko učenje zahtijeva od promatrača da kognitivno sudjeluje u iskustvu, prikupljajući informacije i popunjavajući rupe u znanju o likovno-umjetničkom djelu kojega je vidio.

Komunikacija s likovno-umjetničkim djelom započinje odabirom likovnog djela za prezentaciju. Izbor likovno-umjetničkih djela za učenike nikako ne bi trebao biti slučajan. ${ }^{19}$ Pri odabiru autora i njihovih djela treba povesti računa o sljedećim kriterijima:

»Važnost autora i njegova rada (načelo kvalitete); tipičnost autora i njegova rada (tipični predstavnici pojedinih stilova); zornost radova (ilustracija određenog načina likovnog izražavanja); sadržajna primjerenost radova (izbor radova koji nisu prekompleksni i ne zahtijevaju prethodna znanja, a također i nemaju ekstremne prikaze nasilja, golotinje, spolnosti); praktično-izvedbena primjerenost djela (izabiremo djela na temelju kojih se osvještava određeni likovni zadatak).« ${ }^{20}$

\footnotetext{
${ }^{14}$ Usp. Feldman, nav. dj., 231.

${ }^{15}$ Usp. isto, 232.

${ }^{16}$ Usp. Brajčić, Arheološki parkovi u Hrvatskoj..., 17.

${ }^{17}$ Primjerice, Doris ASH, Gordon WELS, Dialogic inquiry in classroom and museum, u: Z. Berkerman, N. Burbules, D. Silbermann-Keller (ur.), Learning in places. The informal education reader, New York, Peter Lang, 2006, 35-54; Kathy DANKO-MCGREE, Favourite artworks chosen by young children in a museum setting, International Journal of Education through Art, 2 (2006) 3, 223-235; Ann M. COX-PETERSON, David MARSH, James KISIEL, Leah MELBER, Investigation of guided school tours, student learning, and science reform recommendations at a museum of natural history, Journal of Research in Science Teaching, 40 (2003) 2, 200-218.

${ }^{18}$ Usp. Richard LACHAPELLE, Deborah MURRAY, Sandy NEIM, Aesthetic understanding as informed experience. The role of knowledge in our art viewing experiences, Journal of Aesthetic Education, 37 (2003) 3, 78-98.

${ }^{19}$ Usp. Tomaž ZUPANČIĆ, Suvremena umjetnost $i$ njena pedagoška vrijednost. Interdisciplinarni pristup učenju, Rijeka, Učiteljski fakultet sveučilišta u Rijeci, 2009, 272-281.

${ }^{20}$ Matjaž DUH, Tomaž ZUPANČIĆ, Suvremeno likovno stvaralaštvo kao sadržaj likovnoga projekta u vrtiću, u: H. Ivon (ur.), Djeca i mladež u svijetu umjetnosti, Split, Filozofski fakultet Sveučilišta u Splitu, Centar za interdisciplinarne studije Studia Mediterranea, Hrvatski književno pedagoški zbor - ogranak Split, 2009, 51-77, 61.
} 
Koji pristup odabrati i kako komunicirati s likovno-umjetničkim djelom, tema je koja zaokuplja mnoge autore. Feldman ${ }^{21}$ je u svojoj knjizi Postati čovjekom kroz umjetnost predložio model analize i kritike umjetničkog rada koji su kasnije usvojili i modificirali mnogi istraživači i danas je prihvaćen kao standard $\mathrm{u}$ analizi likovno-umjetničkog djela u mnogim školama. U svojem modelu promatranja umjetničkog djela Feldman predlaže četiri faze prosudbe likovno-umjetničkog djela. Te faze uključuju: opisivanje (promatrači opažaju i opisuju ono što vide), analitičku obradu (uočavaju se elementi, principi i tehnike koje umjetnici rabe te se navedeni elementi uspoređuju i suprotstavljaju), interpretaciju (razmatraju se i ispituju mogući ciljevi, teme i razlozi zašto je rad nastao) i evaluaciju (promatrači pokazuju što su naučili dajući osobno mišljenje o umjetničkom radu koji su promatrali). Eisner razlikuje šest dimenzija za promatranje i raspravu o likovno-umjetničkom djelu. ${ }^{22}$ Eisnerove dimenzije uključuju: iskustvenu dimenziju (istražuje se učinak umjetničkog djela na promatrača), formalnu dimenziju (promatrač se usredotočuje na vizualne elemente umjetnosti i principe rada), simboličku i tematsku dimenziju (promatrač analizira i pokušava razumjeti kodirano značenje i temu umjetničkog djela), materijalnu dimenziju (pretpostavlja ispitivanje likovnih materijala, alata i medija i ograničenja koja imaju) te kontekstualnu dimenziju (pretpostavlja ispitivanje konteksta).

Muzejski pedagozi Charman, Rose i Wilson nude model koji potiče estetsko učenje kroz promatranje i doživljavanje likovno-umjetničkih djela. ${ }^{23}$ Taj model promatranja nazvan je Ways in model, a razvijen je još devedesetih godina 20. stoljeća. Shvaćajući važnost kreativnosti u »mišljenju i stvaranju«, model traži četiri pristupa da bi se kod promatrača razvila dubina estetskog iskustva nužna u razumijevanju i interpretaciji umjetničkog djela. Ways in model prikazan je u obliku četiriju krugova u čijem je središtu lik promatrača, jer se osobno prosuđivanje smatra nužnim za uspješnost ovog pristupa podučavanja koje pretpostavlja: osobni pristup (promatranje i socijalno iskustvo koje promatrač donosi u interpretacijsko iskustvo), pristup objektu (analizira se boja, oblik, površina, tekstura, prostor, materijali, vrijeme koje se prikazuje u umjetničkom djelu), pristup subjektu (određuje se opseg, poruka, naslov, žanr i tema umjetničkog djela) te pristup kontekstu (utvrđuje se kako je objekt povezan sa stvarnim svijetom). Učitelj ima sekundarno mjesto u aktivnosti te uglavnom daje zadatke učenicima i potiče učenje postavljanjem pitanja, a djecu stavlja u ulogu istraživača, tražeći da međusobno razmjenjuju znanja. Započinje se učeničkim reakcijama na likovno-umjetničko djelo koje se temelje na osobnom kontekstu, sjećanjima i asocijacijama, a tek se kasnije kreće na kritičku anali-

\footnotetext{
${ }^{21}$ Usp. Feldman, nav. dj., 12.

${ }^{22}$ Usp. Eliot EISNER, Educating artistic vision, New York, Macmillan, 1972, 231.

${ }^{23}$ Usp. Helen CHARMAN, Katherine ROSE, Gillian WILSON (ur.), The Art Gallery Handbook. A Resource for Teachers, London, Tate Publishing, 2006, 38-59, prema Kuščević, nav. dj., 49.
} 
zu likovno-umjetničkog djela. Učenicima se stalno postavljaju pitanja: Koje su tvoje prve reakcije na likovno-umjetničko djelo? Zašto to misliš, osjećaš? Kako tvoja razmišljanja utječu na tvoje stavove? ${ }^{24}$

U nastavnom procesu učitelj ima ulogu kreativnog posrednika između nastavnog gradiva i učenika. Međutim, nastavnik nije samo prijenosnik informacija, već je istodobno i osoba koja obrazovanje čini stvaralačkim činom.

»Uloga nastavnika u odgojno-obrazovnom procesu je nezamjenljiva jer rezultati odgojno-obrazovnog rada ovise o osposobljenosti i domišljatosti nastavnika za obavljanje struke. Nastavnik treba posjedovati praktična i teorijska znanja iz područja likovnog jezika i likovnih tehnika te poznavanja likovnog izraza djece određene dobi i likovno-umjetničkih djela. ${ }^{25}$

»Osnovni razlozi za korištenje likovnoga djela u školama su: 1. razviti kod djece svjesnost, razumijevanje i zahvalnost prema vrijednosti umjetničkih djela, umjetnicima kao dijelu kulturne tradicije; 2 . dopustiti djeci da se identificiraju i istražuju veze između njihovoga praktičnoga rada i likovnih umjetničkih djela; 3. podržati djecu da razviju svoje kritičke vještine gledajući umjetnička djela.« ${ }^{26}$ »Znanje likovnoga jezika i iskustvo gledanja može se steći jedino kontinuiranim susretom s djelima likovnih umjetnosti, njihovim promatranjem i doživljavanjem. Nužan je posredan ili neposredan kontekt djeteta s umjetničkim djelima. $\ll^{27}$

Za svaki pojedini razred u Nastavnom planu i programu predložen je popis likovno-umjetničkih djela-reprodukcija, da bi se na njima istraživali likovni problemi. ${ }^{28}$

\footnotetext{
${ }^{24}$ Prema Brad IRWIN, Learning about art in the classroom. Can we learn some lessons from art gallery practice?, u: P. Smith (ur.), The Arts in Education. Critical Perspectives from Teacher Educators School for Visual and Creative Arts in Education, Auckland, Faculty of Education, The University of Auckland, 2008, 40-56.

${ }^{25}$ Emil R. TANAY, Likovna kultura u nižim razredima osnovne škole, Zagreb, Školska knjiga, 1989, 8.

${ }^{26}$ Usp. Robert WATTS, Using Artists Work, u: S. Cox, R. Watts (ur.), Teaching Art and Design 3-11 Reaching the Standard Series, Trowbridge, Wiltshire, The Cromwell Press Group, 2009, 190-207, 198.

${ }^{27}$ Fehim HUSKOVIĆ, Umjetničke galerije i likovne sposobnosti djeteta, u: H. Ivon (ur.), Djeca $i$ mladež u svijetu umjetnosti, Split, Filozofski fakultet, Centar za interdisciplinarne studije Studia Mediterranea, Hrvatsko pedagoško-književni zbor, Ogranak Split, 2009, 131-135, 133.

${ }^{28}$ Usp. Marijana ŽUPANIĆ-BENIĆ, Uloga učitelja u komunikaciji s likovnim djelom, u: A. BALIĆ ŠIMRAK (ur.), Umjetničko djelo u likovnom odgoju i obrazovanju. Zbornik radova, Zagreb, CNSI, 2011, 144-155, 146.
} 


\section{Metodologija istraživanja}

\subsection{Cilj istraživanja}

Cilj istraživanja bio je utvrditi upotrebljavaju li likovno-umjetničko djelo u nastavi likovne kulture više učitelji ili studenti. Na temelju definiranog problema i cilja istraživanja postavljene su sljedeće hipoteze:

H1: Postoji statistički značajna razlika između učitelja i studenata u upotrebljavanju likovno-umjetničkih djela na nastavi likovne kulture.

H2: Postoji statistički značajna razlika između učitelja i studenata u objašnjavanju, shvaćanju, ilustraciji i uočavanju likovnog jezika na likovnoumjetničkom djelu.

H3: Postoji statistički značajna razlika između učitelja i studenata u prikazivanju figurativnih djela na satovima likovne kulture.

H4: Postoji statistički značajna razlika između učitelja i studenata u prikazivanju apstraktnih djela na satovima likovne kulture.

H5: Postoji statistički značajna razlika između učitelja i studenata u prikazivanju djela domaćih umjetnika.

H6: Postoji statistički značajna razlika između učitelja i studenata u prikazivanju djela stranih umjetnika.

H7: Postoji statistički značajna razlika između učitelja i studenata u poticanju dječjeg izražavanja mišljenja o likovno-umjetničkom djelu.

H8: Postoji statistički značajna razlika između učitelja i studenata u upotrebi likovno-umjetničkog djela kao poticaja za likovno stvaralaštvo.

\subsection{Uzorak ispitanika}

Korišteni uzorak bio je 80 učitelja i 80 studenata, što u ovom slučaju čini reprezentativan uzorak. Anketirani su učitelji s područja Splitsko-dalmatinske županije i studenti četvrte i pete godine Učiteljskog studija Sveučilišta u Splitu. Studenti četvrte i pete godine studija u okviru vježbi iz kolegija Metodika likovne kulture drže probna i ispitna predavanja. Zbog toga su izabrani za usporedbu s učiteljima koji već imaju radnog iskustva.

\subsection{Uzorak varijabli}

Korištene su varijable ekstrahirane iz upitnika (prilog 1): Na svakom satu likovne kulture koristim likovno djelo (Upotreba lik. djela). Preko likovnoumjetničkih djela objašnjavam djeci likovni jezik (Upotreba lik. djela za lik. 
jezik). Pokazivanje likovno-umjetničkih djela izuzetno je važno za shvaćanje likovnoga jezika (Stavovi o lik. djelu). Na satu likovne kulture uglavnom pokazujem figurativna djela (Figurativna djela). Na satu likovne kulture uglavnom pokazujem apstraktna djela (Apstraktna djela). Apstraktna djela rjeđe prikazujem djeci jer ih oni teže razumiju (Apstraktna djela razumijevanje). Pokazujem djela domaćih umjetnika (Domaći umjetnici). Pokazujem djela stranih umjetnika (Strani umjetnici). Upotrebljavam likovno-umjetnička djela kao ilustraciju za likovni jezik (Upotreba lik. djela). Potičem djecu da na likovnome djelu uoče elemente likovnoga jezika (Poticanje uočavanja). Potičem djecu da izraze mišljenje o likovno-umjetničkom djelu (Poticanje mišljenja). Upotrebljavam likovno-umjetničko djelo kao poticaj za likovno stvaranje (Poticanje lik. stvaranja).

\subsection{Metoda obrade podataka}

Za sve varijable izračunani su parametri deskriptivne statistike: aritmetička sredina (AS), medijan (Med), minimalan rezultat (Min), maksimalan rezultat (Maks), standardna devijacija (SD), koeficijent asimetričnosti $\left(\alpha_{3}\right)$ i koeficijent spljoštenosti $\left(\alpha_{4}\right)$. Radi ispitivanja normaliteta distribucije izračunana je značajnost Kolmogorov-Smirnovljeva testa (KSp). Da bismo utrdili postojanje razlika u promatranim varijablama između učitelja i studenata korišten je neparametrijski Mann-Whitney $U$ test te su izračunate sume rangova, $\mathrm{U}$ vrijednost, $\mathrm{Z}$ vrijednost te nivo značajnosti (p). Pogreška prve vrste je postavljena na $\alpha=5 \%$. Svi rezultati su obrađeni korištenjem računalnog paketa Statistica 13.2 (Dell Inc, Tulsa, OK, SAD).

\section{Rezultati i rasprava}

U tablici 1 nalaze se podaci deskriptivne statistike za čitav uzorak. Promatranjem KS testa zaključujemo da sve varijable imaju narušen normalitet distribucije. U ukupnom uzorku možemo vidjeti da je najniži broj kojim je rangirana neka tvrdnja broj 1 , a najviši broj kojim je rangirana neka tvrdnja broj 5 . Kod svih tvrdnji maksimum je broj 5 , a minimum je u većini tvrdnji broj 1, izuzev tvrdnji: Pokazujem djela domaćih umjetnika i Potičem djecu da na likovno-umjetničkom djelu uoče elemente likovnog jezika kod kojih je minimum broj 2 . 
Tablica 1:

\begin{tabular}{|l|c|c|c|c|c|c|c|c|}
\hline \multicolumn{1}{|c|}{ Varijable } & AS & Med & Min & Maks & SD & $\boldsymbol{\alpha}_{3}$ & $\boldsymbol{\alpha}_{\mathbf{4}}$ & KSp \\
\hline Upotreba lik. djela & 4,06 & 4,00 & 1,00 & 5,00 & 1,08 & $-0,96$ & 0,07 & $\mathrm{p}<0,01$ \\
\hline Upotreba lik. djela za lik. jezik & 4,13 & 4,00 & 1,00 & 5,00 & 0,98 & $-0,92$ & 0,15 & $\mathrm{p}<0,01$ \\
\hline Stavovi o lik. djelu & 4,47 & 5,00 & 1,00 & 5,00 & 0,75 & $-1,47$ & 2,39 & $\mathrm{p}<0,01$ \\
\hline Figurativna djela & 3,81 & 4,00 & 1,00 & 5,00 & 0,83 & $-0,25$ & $-0,16$ & $\mathrm{p}<0,01$ \\
\hline Apstraktna djela & 2,95 & 3,00 & 1,00 & 5,00 & 0,89 & $-0,01$ & 0,25 & $\mathrm{p}<0,01$ \\
\hline Apstraktna djela razumijevanje & 3,48 & 4,00 & 1,00 & 5,00 & 1,12 & $-0,54$ & $-0,38$ & $\mathrm{p}<0,01$ \\
\hline Domaći umjetnici & 3,93 & 4,00 & 2,00 & 5,00 & 0,91 & $-0,45$ & $-0,66$ & $\mathrm{p}<0,01$ \\
\hline Strani umjetnici & 4,26 & 4,00 & 1,00 & 5,00 & 0,80 & $-1,04$ & 1,22 & $\mathrm{p}<0,01$ \\
\hline Upotreba lik. djela & 4,06 & 4,00 & 1,00 & 5,00 & 0,85 & $-0,68$ & 0,19 & $\mathrm{p}<0,01$ \\
\hline Poticanje uočavanja & 4,34 & 5,00 & 2,00 & 5,00 & 0,87 & $-1,07$ & 0,09 & $\mathrm{p}<0,01$ \\
\hline Poticanje mišljenja & 4,42 & 5,00 & 1,00 & 5,00 & 0,79 & $-1,52$ & 2,58 & $\mathrm{p}<0,01$ \\
\hline Poticanje lik. stvaranja & 4,29 & 4,00 & 1,00 & 5,00 & 0,84 & $-1,35$ & 2,23 & $\mathrm{p}<0,01$ \\
\hline
\end{tabular}

Legenda: parametri deskriptivne statistike za ukupan uzorak (aritmetička sredina (AS), medijan (Med), minimalan rezultat (Min), maksimalan rezultat (Maks), standardna devijacija (SD), koeficijent asimetričnosti $\left(\alpha_{3}\right)$ i koeficijent spljoštenosti $\left(\alpha_{4}\right)$ i značajnost KS testa (KSp).

Kod svih tvrdnji uočljiva je visoka aritmetička sredina. Najviša je u tvrdnji Pokazivanje likovno-umjetničkih djela izuzetno je važno za shvaćanje likovnog jezika $(4,47)$, a najniža je u tvrdnji Na satu likovne kulture uglavnom pokazujem apstraktna djela $(2,95)$.

Što se tiče standardne devijacije, nema prevelikog odstupanja od odgovora gledajući ukupan uzorak. Najviša standardna devijacija je u tvrdnji Apstraktna djela rjeđe prikazujem djeci jer ih oni teže razumiju $(1,12)$, a najniža je u tvrdnji Pokazivanje likovno-umjetničkih djela izuzetno je važno za shvaćanje likovnog jezika $(0,75)$.

Tablica 2:

\begin{tabular}{|l|c|c|c|c|c|c|c|c|}
\hline \multicolumn{1}{|c|}{ Varijable } & AS & Med & Min & Maks & SD & $\boldsymbol{\alpha}_{3}$ & $\boldsymbol{\alpha}_{4}$ & KSp \\
\hline Upotreba lik. djela & 3,39 & 3,00 & 1,00 & 5,00 & 1,06 & $-0,38$ & $-0,39$ & $\mathrm{p}<0,01$ \\
\hline Upotreba lik. djela za lik. jezik & 3,69 & 4,00 & 1,00 & 5,00 & 1,04 & $-0,45$ & $-0,37$ & $\mathrm{p}<0,01$ \\
\hline Stavovi o lik. djelu & 4,24 & 4,00 & 1,00 & 5,00 & 0,80 & $-1,07$ & 1,89 & $\mathrm{p}<0,01$ \\
\hline Figurativna djela & 3,85 & 4,00 & 1,00 & 5,00 & 0,78 & $-0,55$ & 1,12 & $\mathrm{p}<0,01$ \\
\hline Apstraktna djela & 2,70 & 3,00 & 1,00 & 5,00 & 0,82 & $-0,10$ & 0,24 & $\mathrm{p}<0,01$ \\
\hline Apstraktna djela razumijevanje & 3,75 & 4,00 & 1,00 & 5,00 & 1,07 & $-0,74$ & 0,00 & $\mathrm{p}<0,01$ \\
\hline Domaći umjetnici & 3,88 & 4,00 & 2,00 & 5,00 & 0,96 & $-0,36$ & $-0,88$ & $\mathrm{p}<0,01$ \\
\hline Strani umjetnici & 4,04 & 4,00 & 1,00 & 5,00 & 0,80 & $-0,82$ & 1,47 & $\mathrm{p}<0,01$ \\
\hline Upotreba lik. djela & 3,84 & 4,00 & 1,00 & 5,00 & 0,85 & $-0,44$ & 0,37 & $\mathrm{p}<0,01$ \\
\hline Poticanje uočavanja & 3,96 & 4,00 & 2,00 & 5,00 & 0,91 & $-0,34$ & $-0,90$ & $\mathrm{p}<0,01$ \\
\hline Poticanje mišljenja & 4,17 & 4,00 & 1,00 & 5,00 & 0,94 & $-1,11$ & 0,91 & $\mathrm{p}<0,01$ \\
\hline Poticanje lik. stvaranja & 4,06 & 4,00 & 1,00 & 5,00 & 0,88 & $-1,16$ & 2,22 & $\mathrm{p}<0,01$ \\
\hline
\end{tabular}

Legenda: parametri deskriptivne statistike za poduzorak učitelja (aritmetička sredina (AS), medijan (Med), minimalan rezultat (Min), maksimalan rezultat (Maks), standardna devijacija (SD), koeficijent asimetričnosti $\left(\alpha_{3}\right)$ i koeficijent spljoštenosti $\left(\alpha_{4}\right)$ i značajnost KS testa (KSp). 
Rezultati ispitivanja normaliteta pomoću KS testa pokazuju nam da sve varijable imaju konzistentno narušen normalitet $(\mathrm{KSp}<0,01)$, što nam ukazuje na nužnost upotrebe neparametrijskih statističkih metoda.

U ukupnom uzorku možemo vidjeti da je najniži broj kojim je rangirana neka tvrdnja broj 1, a najviši broj kojim je rangirana neka tvrdnja broj 5 . Kod svih tvrdnji maksimum je broj 5 , a minimum je u većini tvrdnji broj 1 , izuzev tvrdnji Pokazujem djela domaćih umjetnika i Potičem djecu da na likovnoumjetničkom djelu uoče elemente likovnog jezika, kod kojih je minimum broj 2.

Kod svih tvrdnji aritmetička sredina je podjednaka. Najviša je u tvrdnji Pokazivanje likovno-umjetničkih djela izuzetno je važno za shvaćanje likovnoga jezika $(4,24)$, a najniža je u tvrdnji Na satu likovne kulture uglavnom pokazujem apstraktna djela $(2,70)$.

U standardnoj devijaciji nema prevelikog odstupanja od odgovora gledajući poduzorak učitelja. Najviša standardna devijacija je u tvrdnji Apstraktna djela rjeđe prikazujem djeci jer ih ona teže razumiju $(1,07)$, a najniža je u tvrdnji $\mathrm{Na}$ satu likovne kulture uglavnom pokazujem figurativna djela $(0,78)$.

Tablica 3:

\begin{tabular}{|l|c|c|c|c|c|c|c|c|}
\hline \multicolumn{1}{|c|}{ Varijable } & AS & Med & Min & Maks & SD & $\boldsymbol{\alpha}_{3}$ & $\boldsymbol{\alpha}_{4}$ & KSp \\
\hline Upotreba lik. djela & 4,73 & 5,00 & 3,00 & 5,00 & 0,57 & $-1,99$ & 2,95 & $\mathrm{p}<0,01$ \\
\hline Upotreba lik. djela za lik. jezik & 4,58 & 5,00 & 3,00 & 5,00 & 0,67 & $-1,31$ & 0,45 & $\mathrm{p}<0,01$ \\
\hline Stavovi o lik. djelu & 4,70 & 5,00 & 2,00 & 5,00 & 0,62 & $-2,25$ & 4,98 & $\mathrm{p}<0,01$ \\
\hline Figurativna djela & 3,77 & 4,00 & 2,00 & 5,00 & 0,87 & $-0,01$ & $-0,91$ & $\mathrm{p}<0,01$ \\
\hline Apstraktna djela & 3,20 & 3,00 & 1,00 & 5,00 & 0,89 & $-0,08$ & 0,39 & $\mathrm{p}<0,01$ \\
\hline Apstraktna djela razumijevanje & 3,21 & 3,00 & 1,00 & 5,00 & 1,10 & $-0,44$ & $-0,50$ & $\mathrm{p}<0,01$ \\
\hline Domaći umjetnici & 3,98 & 4,00 & 2,00 & 5,00 & 0,87 & $-0,54$ & $-0,34$ & $\mathrm{p}<0,01$ \\
\hline Strani umjetnici & 4,49 & 5,00 & 2,00 & 5,00 & 0,73 & $-1,46$ & 2,00 & $\mathrm{p}<0,01$ \\
\hline Upotreba lik. djela & 4,29 & 4,00 & 2,00 & 5,00 & 0,80 & $-1,03$ & 0,71 & $\mathrm{p}<0,01$ \\
\hline Poticanje uočavanja & 4,71 & 5,00 & 2,00 & 5,00 & 0,64 & $-2,63$ & 7,39 & $\mathrm{p}<0,01$ \\
\hline Poticanje mišljenja & 4,66 & 5,00 & 3,00 & 5,00 & 0,50 & $-1,01$ & $-0,28$ & $\mathrm{p}<0,01$ \\
\hline Poticanje lik. stvaranja & 4,51 & 5,00 & 2,00 & 5,00 & 0,75 & $-1,73$ & 3,04 & $\mathrm{p}<0,01$ \\
\hline
\end{tabular}

Legenda: parametri deskriptivne statistike za poduzorak studenata (aritmetička sredina (AS), medijan (Med), minimalan rezultat (Min), maksimalan rezultat (Maks), standardna devijacija $(\mathrm{SD})$, koeficijent asimetričnosti $\left(\alpha_{3}\right)$ i koeficijent spljoštenosti $\left(\alpha_{4}\right)$ i značajnost KS testa (KSp).

U ukupnom uzorku možemo vidjeti da je najniži broj kojim je rangirana neka tvrdnja broj 1, a najviši broj kojim je rangirana neka tvrdnja broj 5 . Kod svih tvrdnji maksimum je broj 5 , a minimum je u većini tvrdnji broj 2, izuzev tvrdnji Na satu likovne kulture uglavnom pokazujem apstraktna djela i Apstraktna djela rjeđe prikazujem djeci jer ih ona teže razumiju, kod kojih je minimum broj 1, a kod tvrdnji Na svakom satu likovne kulture upotrebljavam likovno-umjetničko djelo, Preko likovno-umjetničkih djela objašnjavam djeci likovni jezik i Potičem djecu da izraze mišljenje o likovno-umjetničkom djelu, minimum je broj 3. 
Kod većine tvrdnji aritmetička sredina je visoka. Najviša je u tvrdnji $\mathrm{Na}$ svakom satu likovne kulture upotrebljavam likovno-umjetničko djelo (4,73), a najniža je u tvrdnji Na satu likovne kulture uglavnom pokazujem apstraktna djela $(3,20)$.

U standardnoj devijaciji postoji veće odstupanje od odgovora uspoređujući poduzorak studenata i poduzorak učitelja. Najviša standardna devijacija je $\mathrm{u}$ tvrdnji Apstraktna djela rjeđe prikazujem djeci jer ih ona teže razumiju $(1,10)$, a najniža je u tvrdnji Potičem djecu da izraze mišljenje o likovnome djelu $(0,50)$.

U tablici 4. nalaze se rezultati Mann-Whitneyeva U-testa koji smo radili zbog narušenog normaliteta distribucije. MannWhitneyev U-test neparametrijski je test sume rangova kojim se provjerava pripadaju li dva uzorka u populacije s istim medijanom. Medijan određuje sredinu distribucije.

Tablica 4:

\begin{tabular}{|l|c|c|c|c|c|}
\hline \multicolumn{1}{|c|}{ Varijable } & Suma rangova U & Suma rangova S & $\mathbf{U}$ & $\mathbf{Z}$ & $\mathbf{p}$ \\
\hline Upotreba lik. djela & 4152,50 & 8727,50 & 912,50 & $-8,33$ & 0,000 \\
\hline Upotreba lik. djela za lik. jezik & 4851,00 & 8029,00 & 1611,00 & $-5,81$ & 0,000 \\
\hline Stavovi o lik. djelu & 5321,50 & 7558,50 & 2081,50 & $-4,38$ & 0,000 \\
\hline Figurativna djela & 6633,50 & 6246,50 & 3006,50 & 0,70 & 0,482 \\
\hline Apstraktna djela & 5459,50 & 7420,50 & 2219,50 & $-3,63$ & 0,000 \\
\hline Apstraktna djela razumijevanje & 7325,00 & 5555,00 & 2315,00 & 3,15 & 0,002 \\
\hline Domaći umjetnici & 6270,00 & 6610,00 & 3030,00 & $-0,61$ & 0,542 \\
\hline Strani umjetnici & 5376,50 & 7503,50 & 2136,50 & $-3,95$ & 0,000 \\
\hline Upotreba lik. djela & 5463,00 & 7417,00 & 2223,00 & $-3,33$ & 0,001 \\
\hline Poticanje uočavanja & 4903,00 & 7977,00 & 1663,00 & $-5,24$ & 0,000 \\
\hline Poticanje mišljenja & 5531,50 & 7348,50 & 2291,50 & $-3,10$ & 0,002 \\
\hline Poticanje lik. stvaranja & 5414,00 & 7466,00 & 2174,00 & $-3,50$ & 0,000 \\
\hline
\end{tabular}

Legenda: rezultati Mann-Whitneyeva U-testa za sve varijable. Suma rangova U - suma rangova rezultata učitelja, Suma rangova S - suma rangova rezultata studenata, U - vrijednost U-testa, $\mathrm{Z}$ - vrijednost Z-testa, $\mathrm{p}$ - značajnost razlika među grupama.

Tablica 4. prikazuje statističku značajnost razlika medijana u dvjema promatranim grupama ispitanika. Usporedit ćemo sume rangova za učitelje i sume rangova za studente i $p$. Na postojanje statističke značajnosti razlike medijana u dvjema promatranim grupama možemo odmah vidjeti po $p$ koje, ako je manje od 0,05 , pokazuje na postojanost statistički značajne razlike.

Za tvrdnju Na svakom satu likovne kulture upotrebljavam likovno-umjetničko djelo suma rangova studenata dvostruko je veća nego kod učitelja, a $p$ je 0,000 , što nam ukazuje na to da studenti na satu likovne kulture više upotrebljavaju likovno-umjetničko djelo. Samim tim, potvrđena je i prva hipoteza.

H1: Postoji statistički značajna razlika između učitelja i studenata u upotrebi likovno-umjetničkog djela na nastavi likovne kulture. 
Ova je hipoteza potvrđena u korist studenata. Očekivalo bi se da će učitelji na nastavi likovne kulture više upotrebljavati likovno-umjetničko djelo. Međutim, pokazalo se suprotno. Objašnjenje leži u tome da se studenti pripremaju za ogledne satove uz pratnju mentora koji skrbi da ispitni i ogledni sat ne protekne bez prikaza likovno-umjetničkog djela.

Rezultati su u skladu s istraživanjem koje je o ovoj temi provedeno 2011. godine na području Zagreba i Rijeke na uzorku od 124 učiteljice, a ono je pokazalo da dvije trećine ispitanica drži da je upotreba likovno-umjetničkog djela bitna za kvalitetu nastave likovne kulture. ${ }^{29}$ Rezultati ovih dvaju istraživanja nisu u nesuglasju. Iako je riječ o visokom postotku pozitivnih odgovora učiteljica na ovo pitanje, ako to istraživanje usporedimo sa sadašnjim u kojim je vidljiva prednost studenata u odnosu na učitelje, očito je da je potrebna dodatna edukacija učitelja da bi se podigla svijest o važnosti i ulozi likovno-umjetničkog djela u nastavi likovne kulture.

Tvrdnja Preko likovnih djela objašnjavam djeci likovni jezik pokazuje također skoro dvostruko veću sumu rangova studenata od učitelja, a $p$ je opet 0,000 , što ukazuje na to da studenti putem likovnih djela češće objašnjavaju likovni jezik nego učitelji.

Kada se napravi usporedba s već spomenutim istraživanjem o ovoj temi, iako je pitanje bilo nešto drugačije formulirano, rezultati su pokazali da više od tri četvrtine učiteljica provjerava kod učenika poznavanje i razumijevanje likovnih pojmova putem analize likovno-umjetničkog djela. Ovakvi rezultati govore o visokoj svijesti učitelja o biti interakcije učenika s likovno-umjetničkim djelom, ali ako se usporedi s rezultatima sadašnjeg istraživanja, čini se ipak nedovoljno jer su studenti pokazali prednost u odnosu na učitelje. Pohvale idu studentima, njihovim profesorima i mentorima, ali opet moramo istaknuti nužnost dodatne edukacije učitelja, zbog podizanja svijesti o značenju ovog pitanja.

Pokazivanje likovno-umjetničkih djela izuzetno je važno za shvaćanje likovnoga jezika jest tvrdnja u kojoj je suma rangova studenata opet veća od sume rangova učitelja, a $p$ je opet 0,000 i to također ukazuje na to da studenti češće smatraju da je pokazivanje likovnih djela važno za shvaćanje likovnosti.

Kod tvrdnje Na satu likovne kulture uglavnom pokazujem figurativna djela nema velike razlike među sumama rangova studenata i učitelja. Kod ove tvrdnje suma rangova učitelja je veća, ali ne značajno jer je $p 0,482$ i pokazuje da nema statističke značajnosti između učitelja i studenata u prikazivanju figurativnih djela na satovima likovne kulture, $\mathrm{tj}$. obje ispitane skupine prikazuju ih jednako često. Prema tome, nije potvrđena treća hipoteza.

H3: Postoji statistički značajna razlika između učitelja i studenata u prikazivanju figurativnih djela na satovima likovne kulture. Učitelji i studenti u podjednakoj mjeri prikazuju djeci na nastavi likovne kulture figurativna djela.

${ }^{29}$ Usp. Županić-Benić, nav. dj., 150. 
Tvrdnja Na satu likovne kulture uglavnom pokazujem apstraktna djela pokazuje veću sumu rangova studenata od sume rangova učitelja, a $p$ je 0,000 , što ukazuje na postojanje statističke značajnosti u prikazivanju apstraktnih djela na satovima likovne kulture između učitelja i studenata. Studenti češće prikazuju apstraktna djela od učitelja.

Kod tvrdnje Apstraktna djela rjeđe prikazujem djeci jer ih ona teže razumiju suma rangova učitelja veća je od sume rangova studenata, a $p$ je 0,002 , što ukazuje na to da učitelji rjeđe prikazuju apstraktna djela djeci.

»Umjetničko djelo nije u funkciji ilustracije motiva, već je ono samo ilustracija likovnog problema koje će učenici rješavati, treba sadržajem, a ne temom odgovarati likovnom području. «30

Prema ovom dokumentu razvidno je da tema likovno-umjetničkog djela nije značajna za rješavanje likovnog problema. Rezultati pokazuju da su studenti upoznati s Nastavnim planom i programom za osnovnu školu i primjenjuju ga u ovom segmentu, međutim razlika u rezultatima kod učitelja pokazuje da je provedba u praksi upitna. Zadaća učitelja je da djeci na adekvatan način približi likovno-umjetničko djelo. Proučavanje likovno-umjetničkog djela pruža učenicima mogućnost da razviju sposobnost uočavanja, mišljenja i izražavanja kroz umjetnost. Učiteljeva je uloga da podrži razvoj tih kompetencija putem odabira likovno-umjetničkih djela, njihova predstavljanja, te da usmjerava razgovor o likovno-umjetničkom djelu. Zbog toga je potrebno na isti način tretirati i figurativna i apstraktna likovno-umjetnička djela jer se bit nalazi u uočavanju likovnog problema, a ne u samoj temi djela. Dapače, potrebno je na pravi način demistificirati učenicima pojam apstrakcije i usmjeriti ih na uočavanje apstraktnog u svakoj figuraciji.

Kod ovih dviju tvrdnji potvrđena je četvrta hipoteza.

H4: Postoji statistički značajna razlika između učitelja i studenata u prikazivanju apstraktnih djela na satovima likovne kulture.

Pokazujem djela domaćih umjetnika jest tvrdnja koja ne daje preveliku razliku sume rangova učitelja i studenata. Suma rangova studenata malo je veća, ali ne značajno jer je $p 0,542$, što ukazuje na to da i studenti i učitelji podjednako često prikazuju djela domaćih umjetnika i, prema tome, nema statistički značajne razlike među njima, pa peta hipoteza nije potvrđena.

H5: Postoji statistički značajna razlika između učitelja i studenata u prikazivanju djela domaćih umjetnika. Ova hipoteza nije potvrđena jer ne postoji statistički značajna razlika između učitelja i studenata u prikazivanju djela domaćih autora. Učitelji i studenti podjednako često, na nastavi likovne kulture prikazuju djela domaćih umjetnika.

U tvrdnji Pokazujem djela stranih umjetnika suma rangova studenata veća je od sume rangova učitelja, a $p$ je 0,000 i ukazuje na postojanje statističke značajnosti u prikazivanju djela stranih umjetnika na satovima likovne kulture

\footnotetext{
${ }^{30}$ Nastavni plan i program za osnovnu školu HNOS (2006), www.mzos.hr, 53.
} 
između učitelja i studenata, tj. studenti češće pokazuju djela stranih umjetnika. Prema tome, potvrđena je šesta hipoteza.

H6: Postoji statistički značajna razlika između učitelja i studenata u prikazivanju djela stranih umjetnika. Ova hipoteza potvrđena je u korist studenata jer se pokazalo da oni češće prikazuju djela stranih umjetnika nego učitelji.

Kod tvrdnje Upotrebljavam likovno-umjetnička djela kao ilustraciju za likovni jezik suma rangova studenata veća je od sume rangova učitelja, a $p$ je 0,001 , što ukazuje na to da studenti češće upotrebljavaju likovna djela kao ilustraciju za likovni jezik.

Potičem djecu da na likovno-umjetničkom djelu uoče elemente likovnoga jezika jest tvrdnja u kojoj je suma rangova studenata veća od sume rangova učitelja, a $p$ je 0,000 , što ukazuje na to da studenti više potiču djecu na uočavanje elemenata likovnog jezika na likovno-umjetničkom djelu.

U tvrdnjama Preko likovno-umjetničkih djela objašnjavam djeci likovni jezik, Pokazivanje likovno-umjetničkih djela izuzetno je važno za shvaćanje likovnoga jezika, Upotrebljavam likovno-umjetnička djela kao ilustraciju za likovni jezik i Potičem djecu da na likovno-umjetničkom djelu noče elemente likovnoga jezika postoji statistički značajna razlika između učitelja i studenata pa je potvrđena i druga hipoteza.

H2: Postoji statistički značajna razlika između učitelja i studenata u objašnjavanju, shvaćanju, ilustraciji i uočavanju likovnoga jezika na likovno-umjetničkom djelu.

I ova hipoteza je potvrđena u korist studenata, što govori da studenti češće objašnjavaju djeci likovni jezik putem likovnih djela, smatraju da je pokazivanje likovnih djela važno za shvaćanje likovnoga jezika, upotrebljavaju likovna djela kao ilustraciju za likovni jezik i potiču djecu na uočavanje elemenata likovnog jezika na likovno-umjetničkom djelu.

Potičem djecu da izraze mišljenje o likovno-umjetničkom djelu jest tvrdnja u kojoj je suma rangova studenata veća od sume rangova učitelja, a $p$ je 0,002 , što ukazuje na to da studenti više potiču djecu da izraze svoje mišljenje o likovnoumjetničkom djelu. Prema tome, potvrđena i je sedma hipoteza.

H7: Postoji statistički značajna razlika između učitelja i studenata u poticanju dječjeg izražavanja mišljenja o likovno-umjetničkom djelu. Također je i ova hipoteza potvrđena $u$ korist studenata.

Tvrdnja Upotrebljavam likovno-umjetničko djelo kao poticaj za likovno stvaranje pokazuje veću sumu rangova studenata nego sumu rangova učitelja, a $p$ je 0,000 , što ukazuje na postojanost statističke značajnosti između učitelja i studenata u upotrebi likovno-umjetničkog djela kao poticaja za likovno stvaranje, tj. studenti češće upotrebljavaju likovno-umjetničko djelo kao poticaj za likovno stvaranje. Prema tome, potvrđena je i osma hipoteza.

H8: Postoji statistički značajna razlika između učitelja i studenata u upotrebi likovno-umjetničkog djela kao poticaja za likovno stvaralaštvo. 
Zašto i ova hipoteza ide u korist studentima moglo bi se objasniti nedovoljnom upućenosti učitelja u noviju literaturu iz ovog područja. Upotrebu metode estetskog transfera objasnili su brojni autori s područja likovne metodike te bi bilo važno učitelje dodatnim edukacijama upoznati s novijom literaturom i istraživanjima iz područja likovne metodike.

\section{Zaključak}

Glavni cilj istraživanja bio je utvrditi upotrebljavaju li više u nastavi likovne kulture likovno-umjetničko djelo učitelji ili studenti. Pored ovoga, željelo se utvrditi objašnjavaju li putem njih likovni jezik, drže li da je likovno djelo važno za shvaćanje likovnoga jezika, upotrebljavaju li likovno-umjetničko djelo kao ilustraciju za likovni jezik, potiču li djecu da na likovno-umjetničkom djelu uoče elemente likovnoga jezika, pokazuju li figurativna i apstraktna djela, djela domaćih i stranih umjetnika, potiču li djecu da izraze mišljenje o likovnoumjetničkom djelu i upotrebljavaju li ga kao poticaj za likovno stvaralaštvo. Bilo je postavljeno osam hipoteza. Rezultati su pokazali da studenti češće upotrebljavaju likovno-umjetnička djela na nastavi likovne kulture, objašnjavaju djeci likovni jezik preko likovno-umjetničkih djela, smatraju da je likovno-umjetničko djelo važno za shvaćanje likovnoga jezika, koriste likovno-umjetničko djelo kao ilustraciju za likovni jezik, potiču djecu da uoče elemente likovnoga jezika na likovno-umjetničkom djelu, pokazuju apstraktna djela i djela stranih umjetnika, potiču djecu da izraze mišljenje o likovno-umjetničkom djelu i upotrebljavaju ga kao poticaj za likovno stvaralaštvo. Podjednako često učitelji i studenti pokazuju djeci figurativna djela i djela domaćih umjetnika.

Nakon ovoga istraživanja nameće se pitanje zašto su učitelji zakazali u spomenutim varijablama premda u radu s djecom imaju više iskustva od studenata. Međutim, moramo uzeti u obzir da se studenti pripremaju za nastavu samo jednog nastavnog predmeta, da ogledni sat pripremaju uz pomoć mentora koji skrbi da sat bude uzorno proveden i da su paralelno slušali predavanja profesora metodike. Objašnjenje zašto su učitelji podbacili u ovom segmentu rada možda treba tražiti u preopterećenosti sadržajima ostalih predmeta i brojnim odgojnim zadaćama koje im se nameću. Također, možda i nedovoljno pohađanje seminara i nedovoljno praćenje suvremene literature uzrokuje ovakve rezultate. Istraživanje je u svakom slučaju pokazalo da se studenti na fakultetu pravilno pripremaju za rad s djecom na području likovne kulture, a da bi trebalo povesti više brige o stručnim usavršavanjima učitelja u ovom području, da bi što bolje zadovoljili u svim segmentima i lakše odgovorili na izazove odgoja i obrazovanja u današnjem društvu. 


\section{Marija Brajčić* - Mara Šućur*** \\ Approach to the Artistic Work in Teaching Vizual Arts}

Summary

Introducing students with the artwork is a significant goal of the subject of visual arts. The influence of the artwork on child perception, the power of observation and the development of aesthetic values is extremely important for the further development and advancement of students not only in visual arts but also in other educational areas. Scientific theory consider that no curriculum lesson of art classes should go without displaying an artwork.

The aim of the research was to determine the way of using art works in the teaching of fine arts in the lower grades of elementary school. Compared to 80 teachers from Splitsko - dalmatinska County and 80 students of the fourth and fifth year of the Teacher's Study in Split, who are conducting test workshops in the field of visual arts. The purpose of the research was to determine to what extent teachers or students use artwork in the teaching of visual arts and how they represent them to the students. The research has shown that most of the variables mentioned are beneficial to students, with the exception of issues related to the display of figurative works in visual art and showing the works of domestic artists in the teaching of visual culture where there is no statistical significance. Teachers and students choose likewise figurative works and works of domestic artists. The research has shown that most of the above variables are beneficial to students, with the exception of issues related to the display of figurative works in the teaching of visual arts and showing the works of domestic artists in the teaching of visual arts, where there is no statistical significance. Teachers and the students chose equally the figurative works and works of domestic artists.

Key words: art, artwork, teachers, students.

(na eng. prev. Mara Šućur)

\footnotetext{
* Marija Brajčić, PhD, Assis. Prof., Faculty of Humanities and Social Sciences; Address: Poljička cesta 35, HR-21000 Split, Croatia; E-mail: mbrajcic@ffst.hr.

** Mara Šućur, M.Ed, Address: Put Šućura 9, HR-21262 Kamenmost, Imotski, Croatia; E-mail: sucurmara@gmail.com.
} 